\title{
Impact of progesterone and estradiol treatment before the onset of the breeding period on reproductive performance of Bos indicus beef heifers
}

\author{
M.F. Sá Filho ${ }^{a, *}$, L.F.T. Nasser ${ }^{b}$, L. Penteado ${ }^{c}$, R. Prestes ${ }^{c}$, M.O. Marques ${ }^{d}$, \\ B.G. Freitas ${ }^{a}$, B.M. Monteiro ${ }^{a}$, R.M. Ferreira ${ }^{a}$, L.U. Gimenes ${ }^{\mathrm{e}}$, P.S. Baruselli ${ }^{\mathrm{a}, *}$ \\ a Departmento de Reprodução Animal (VRA), FMVZ-USP, São Paulo, Brazil \\ b Born Technologies, Panama City, Panama \\ c Firmasa Tecnologia para Pecuária, Londrina, Paraná, Brazil \\ d Geraembryo, Cornélio Procópio, Paraná, Brazil \\ e Departamento de Medicina Veterinária Preventiva e Reprodução Animal, FCAV-UNESP, Jaboticabal, São Paulo, Brazil
}

\section{A R T I C L E I N F O}

\section{Article history:}

Received 6 March 2015

Received in revised form 23 June 2015

Accepted 26 June 2015

Available online 30 June 2015

\section{Keywords:}

Anestrous

Bovine

Puberty

Reproduction

Reproductive efficiency

\begin{abstract}
A B S T R A C T
The present aimed to develop a hormonal therapy based on the insertion of a progesterone (P4) insert (PI) during $10 \mathrm{~d}$ plus an estradiol injection (E2) at PI removal before the onset of breeding of beef heifers. In Exp. 1, the plasma P4 profile of prepubertal heifers showed that the insertion of a PI or $24 \mathrm{~d}$ previously used P4 insert (UPI) sustained plasma P4 above $1 \mathrm{ng} / \mathrm{mL}$ for at least the first $7 \mathrm{~d}$ of the treatment. In Exp. 2 there was no positive effect of additional estradiol benzoate (EB) administered at the insertion of UPI on the proportion of heifers with a corpus luteum (CL/Treated) $30 \mathrm{~d}$ after UPI removal [UPI $+\mathrm{EB}=85.3 \%^{\mathrm{a}}(n=134)$; $\mathrm{EB}+\mathrm{UPI}+\mathrm{EB}=80.8 \%^{\mathrm{a}}(n=125)$ ]; however, both were greater $(P<0.0001)$ than the Control group $[60.3 \%$ b $(n=129)]$. In Exp. 3, a positive effect $(P=0.01)$ of UPI treatment and both E2 supplementations [EB and estradiol cypionate (EC); $P=0.10$ ] at the UPI removal was observed on $\mathrm{CL} /$ Treated [Control $=42.5 \% \mathrm{~b}$ $(n=94) ; \mathrm{UPI}=58.5 \% \mathrm{a}(n=130) ; \mathrm{UPI}+\mathrm{EB}=64.0 \% \mathrm{a}(n=128) ; \mathrm{UPI}+\mathrm{EC}=67.2 \% \mathrm{a}(n=128)]$. However, greater pregnancy per treated heifer $(\mathrm{P} /$ Treated) following artificial insemination $(\mathrm{AI})$ upon estrus detection was achieved when $\mathrm{EC}$ was applied [Control $=20.2 \%$; UPI $=29.2 \%{ }^{\mathrm{ab}}$; $\mathrm{UPI}+\mathrm{EB}=26.6 \%^{\mathrm{b}}$; UPI $\left.+\mathrm{EC}=36.7 \%^{\mathrm{a}}\right]$. In Exp. 4 , the treatment prior to the timed AI (TAI) tended to improve pregnancy per TAI [P/AI; Control $43.6 \%(n=298) v$ s. UPI +EC $51.9 \%$ $(n=342) ; P=0.08$ ], but increased $\mathrm{P} /$ Treated [26.5\% vs. 43.3\%; $P<0.001$ ]. Thus, UPI +EC treatment were efficient in increasing the $\mathrm{CL} /$ Treated, tended to improve the $\mathrm{P} / \mathrm{AI}$ and consequently enhanced $\mathrm{P} /$ Treated of zebu beef heifers.
\end{abstract}

(c) 2015 Elsevier B.V. All rights reserved.

\section{Introduction}

Reproductive failure can severely impact cow-calf operation profitability and age at puberty is an important factor

\footnotetext{
* Corresponding authors at: Av. Prof. Dr. Orlando Marques de Paiva, 87, Cidade Universitária, 05508-270, São Paulo, SP, Brazil.

E-mail addresses: manoelsa@usp.br (M.F. Sá Filho), barusell@usp.br (P.S. Baruselli).
}

that determines heifer stayability and cow lifetime productivity (Cushman et al., 2013; Ferrell, 1982; Funston et al., 2012b; Patterson et al., 1992). In Brazil, puberty in Bos indicus beef heifers is estimated to occur at 22-36 months and age at first calving at around 44-48 months of age (Nogueira, 2004; Sartori et al., 2010). When compared to Bos taurus, which reach puberty around $15 \mathrm{mo}$, this delay observed in $B$. indicus heifers is attributed to both genetic (Eler et al., 2002) and environmental factors, including 
nutrition, disease, temperature, Humidity and season of birth (Nogueira, 2004; Sartori et al., 2010).

In pasture-based production systems for beef cattle, typical of tropical production systems, the use of restricted periods of breeding requires that heifers attain puberty before the onset of the breeding period (BP). It is known that heifers attaining puberty early have greater reproductive performance and greater chance of re-conception after first calving (Funston et al., 2012a). In addition, heifers with a corpus luteum (CL) at the beginning of the synchronization protocol have greater pregnancy per artificial insemination $(\mathrm{P} / \mathrm{AI})$ in comparison to those without a CL (Sá Filho et al., 2010b). Strategic exposure of prepubertal heifers to exogenous progesterone $(\mathrm{P} 4)$ can be used to modulate their hypothalamus, increasing gonadotropin secretion (Day, 1987; Graden et al., 1968; Yavas and Walton, 2000) and inducing puberty (Anderson et al., 1996; Claro et al., 2010; Grings et al., 1998; Hall et al., 1997; Imwalle et al., 1998). Thus, exposing zebu beef heifers to an exogenous source of $\mathrm{P} 4$ prior to the onset of breeding could increase cyclicity and the number of pregnant heifers early in the BP.

In $B$. indicus heifers, $\mathrm{P} 4$ administered via intravaginal P4-releasing inserts has effectively hastened puberty and improved service rate at the onset of the BP (Claro et al., 2010; Rodrigues et al., 2014, 2013). However, despite the beneficial effects of this hormonal therapy, previous studies fail to demonstrate the amount of P4 delivered during treatment when employing a used P4 insert (UPI), which is expected to determined lower P4 circulating concentration, in comparison to a new P4 insert (PI; Dias et al., 2009). Furthermore, the importance of administrating an estradiol ester at P4 insert removal and the type of estradiol (E2) ester [E2 benzoate (EB) or E2 cypionate (EC)] are questions to be considered. Finally, the impact of inducing puberty before the onset of the BP on P/AI remains unclear.

Therefore, the objectives of this sequence of studies were to test a P4 plus E2-based protocol to increase the number of $B$. indicus beef heifers presenting a $\mathrm{CL}$ at the onset of the BP (Exp. 1-3); and to evaluate the impact of this hormonal therapy on P/AI of beef heifers presenting $\mathrm{CL}$ at onset of the synchronization protocol (Exp. 4). We hypothesized that treatment with exogenous P4 plus E2 would increase the number of $B$. indicus beef heifers presenting a $\mathrm{CL}(\mathrm{CL} /$ treated), the $\mathrm{P} / \mathrm{AI}$ and, consequently, the pregnancy per treated heifer $(\mathrm{P} /$ Treated).

\section{Materials and methods}

\subsection{Experiment 1: $P 4$ profile of heifers treated with $P 4$ inserts}

\subsubsection{Location and animals}

This experiment was conducted at the São Paulo University Beef Cattle Research Center located in Pirassununga, São Paulo, Brazil. All heifers were kept on Brachiaria decumbens pasture and had access to mineral supplement and water. Twenty seven Nelore (B. indicus) beef prepubertal heifers from 20 to 22 months of age were enrolled in the study. On the first day of treatment all heifers were weighed using digital cattle weight scales without food or water restriction and body condition score (BCS) was recorded using a $1-5$ point scale ( $1=$ emaciated, $5=$ obese) (Ayres et al., 2009).

\subsubsection{Experimental design and ultrasound examination}

Two consecutive transrectal ultrasound examinations (5 MHz, Chison 500VET ${ }^{\circledR}$, Kylumax Eletromedicina LTDA, Brazil) were performed to evaluate cyclicity status (Days -7 and 0 ) of all heifers (Fig. 1). Only prepubertal heifers were eligible for the experiment; heifers with a corpus luteum (CL) detected at least once were excluded. The remaining $(n=27)$ heifers were randomly assigned to one of the three following treatments: Control untreated heifers $(n=8)$; PI [ $n=10$; insertion of a PI containing $1.9 \mathrm{~g}$ of P4 (CIDR ${ }^{\circledR}$, Zoetis, São Paulo, Brazil)]; or UPI [( $n=9$; insertion of a UPI). The UPI insert has been previously utilized in suckled beef cows for three 8 day periods, summarizing 24 days of use. After each use, the UPI were individually washed with water and soaked in a solution of chloride alkyl dimethyl benzyl ammmonium (CB 30 Ourofino Agronegócio, São Paulo, Brazil) for $\sim 10$ min. Thereafter, the inserts were dried using brown paper, placed into plastic bags and stored at room temperature, in a clean environment. After $10 \mathrm{~d}$ (Day 10), the P4 insert was removed.

Blood samples were collected from the jugular vein in $10 \mathrm{~mL}$ heparinized tubes (Vacutainer ${ }^{\circledR}$, Becton Dickinson and Company, USA) on Days 0, 1, 4, 7, 10 and 20 (Fig. 1). Samples were promptly centrifuged at $1500 \times g$ and plasma was stored at $-20^{\circ} \mathrm{C}$ until analyzed. The plasma P4 concentration was determined by a solid-phase radioimmunoassay (Coat-a-Count ${ }^{\circledR}$, Diagnostic Products Corporation, Los Angeles, CA, USA). The P4 assay sensitivity was $0.072 \mathrm{ng} / \mathrm{mL}$ and the inter- and intra-assay coefficients of variation were 6.71 and $9.08 \%$, respectively. Another transrectal ultrasound examination was performed on Day 20 , in order to evaluate ovulation occurrence (i.e. presence of a $\mathrm{CL}$ ).

\subsection{Experiment 2: Combining the use of $E B$ at the beginning and end of $\mathrm{P} 4$ treatment}

\subsubsection{Location and animals}

This experiment was conducted in three commercial beef farms located in Cascavel, Paraná, Brazil. All heifers remained on $B$. decumbens pasture and received mineral supplement and water ad libitum. A total of 388 Nelore ( $B$. indicus) beef heifers ranging from 23 to 26 months of age were enrolled in the study. The BCS was recorded on the first day of treatment using a $1-5$ point scale ( $1=$ emaciated, 5 = obese) (Ayres et al., 2009).

\subsubsection{Experimental design and ultrasound examination}

On the first day of the trial (Day 0), heifers were examined by transrectal ultrasound; only heifers without a CL were eligible for the study. Heifers were randomly assigned to one of the three following treatments: Control $(n=129$; untreated heifers); UPI + EB [ $n=134$; insertion of a UPI plus $1 \mathrm{mg}$ of EB (i.m., Estrogin ${ }^{\circledR}$, Farmavet, São Paulo, Brazil) at P4 insert removal on Day 10]; and EB + UPI + EB $(n=125$; same treatment as UPI +EB group plus $2 \mathrm{mg}$ EB i.m. at P4 insert insertion) (Fig. 2). Before insertion, the PI were previously used and washed as described in Exp. 1. 


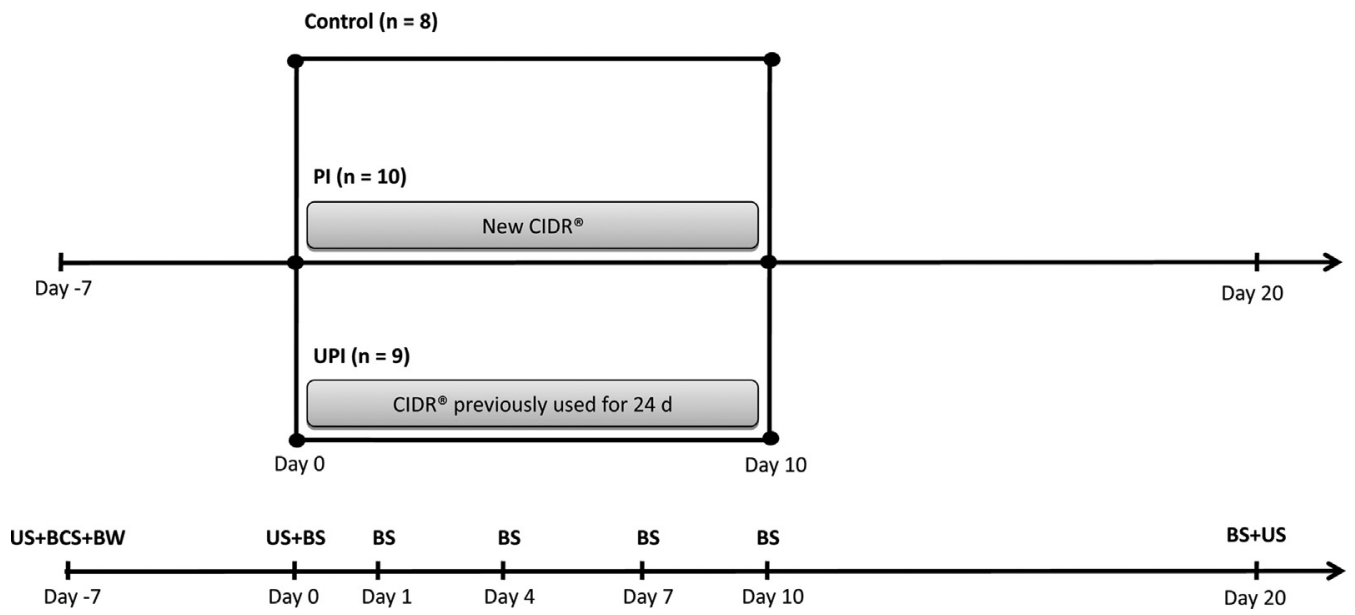

Fig. 1. Design of Experiment 1. Heifers received none (Control), a new intravaginal insert containing $1.9 \mathrm{~g}$ progesterone (PI) or a $24 \mathrm{~d}$ previously used P4 insert (UPI) during $10 \mathrm{~d}$. Ultrasound examinations were done in order to evaluate the presence of a corpus luteum (CL) in ovaries. Blood samples were collected to determine the plasma P4 concentration. US: ultrasound (evaluation of the presence of a CL); BCS: body condition score; BW: body weight.

On Day 40, ovaries were scanned via transrectal ultrasound. Heifers, regardless of the presence of $\mathrm{CL}$, were treated with a protocol for estrus and ovulation synchronization, consisting of a $3 \mathrm{mg}$ norgestomet (NORG) ear implant $\left(\right.$ Crestar $^{\circledR}$, MSD Animal Health, São Paulo, Brazil) and $2 \mathrm{mg}$ EB i.m. At the NORG ear implant removal $8 \mathrm{~d}$ later, all heifers received an i.m. injection of $150 \mu \mathrm{g}$ of Dcloprostenol (Preloban ${ }^{\circledR}$, MSD Animal Health, São Paulo, Brazil) and $300 \mathrm{IU}$ of equine chorionic gonadotropin (eCG; Folligon ${ }^{\circledR}$, MSD Animal Health, São Paulo, Brazil). Ovulation was induced with $1 \mathrm{mg}$ EB i.m. $24 \mathrm{~h}$ after NORG implant removal and TAI was performed $24 \mathrm{~h}$ afterward. Pregnancy diagnosis was performed $30 \mathrm{~d}$ after TAI by transrectal ultrasound examination.

\subsection{Experiment 3: Using different esters of E2 at the conclusion of $\mathrm{P} 4$ treatment}

\subsubsection{Location and animals}

This experiment was conducted on three commercial beef farms located in Cascavel, Paraná, Brazil. All heifers remained on $B$. decumbens pasture with free access to mineral supplement and water. Four hundred and eighty Nelore (B. indicus) beef heifers from 23 to 26 months of age were enrolled in the study. Body condition score was recorded on the first day (Day 0 ) of the trial and on the first day of the BP (Day 40), using a $1-5$ scale ( $1=$ emaciated, 5 =obese) (Ayres et al., 2009). The BCS changes between Day 0 and Day 40 were calculated and heifers were

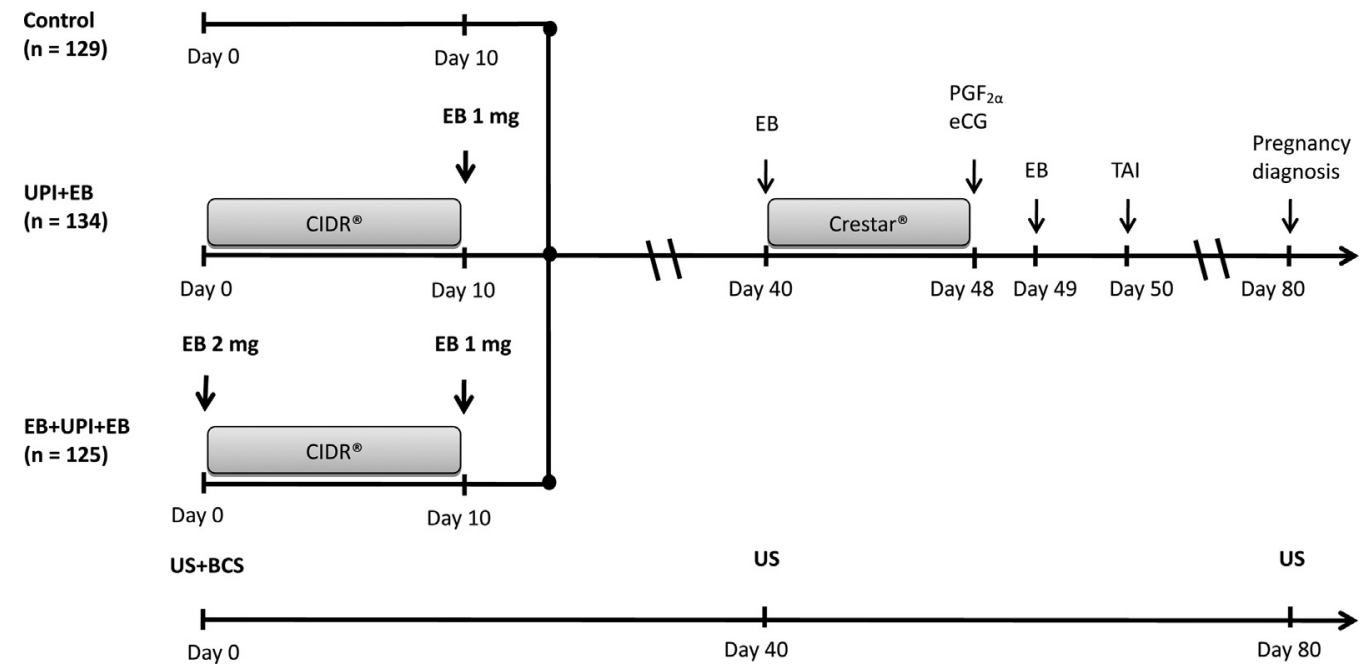

Fig. 2. Design of Experiment 2. Heifers received none (Control), a $24 \mathrm{~d}$ previously used $1.9 \mathrm{~g}$ P4 intravaginal insert (UPI) during $10 \mathrm{~d}$ plus estradiol benzoate (EB) only at the end (UPI+EB) or at the beginning and end of UsediP4 treatment (EB + UPI + EB). Thirty days later, all treated heifers were subjected to a timed artificial insemination (TAI) protocol [Norgestomet ear implant plus $2 \mathrm{mg}$ EB $-8 \mathrm{~d}-150 \mu \mathrm{g}$ D-cloprostenol (PGF $2 \alpha)$ and $300 \mathrm{IU}$ equine chorionic gonadotropin $((\mathrm{eCG})-24 \mathrm{~h}-1 \mathrm{mg}$ EB i.m. $-24 \mathrm{~h}-\mathrm{TAI})$. Pregnancy diagnosis was performed $30 \mathrm{~d}$ after TAI by ultrasound. US: ultrasound; BCS: Body condition score. 


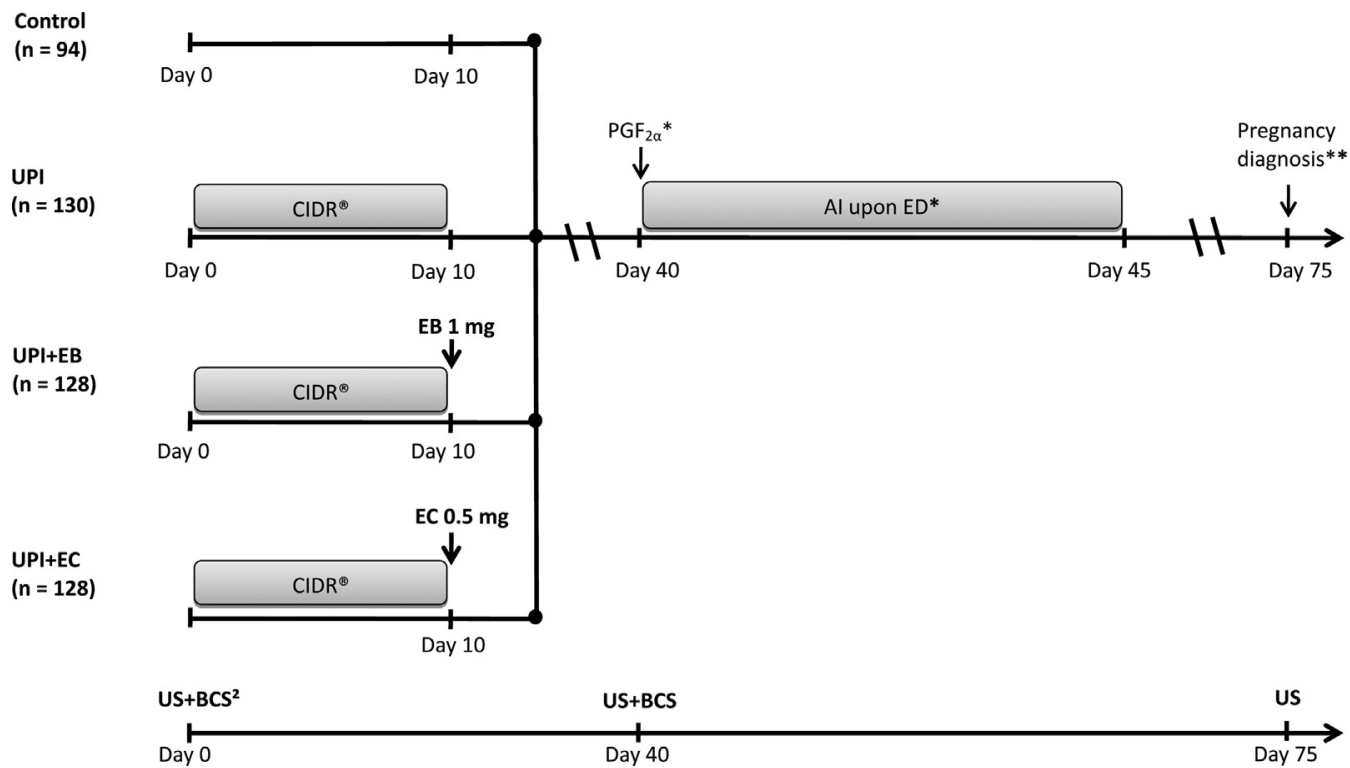

Fig. 3. Design of Experiment 3. Heifers received none (Control), a $24 \mathrm{~d}$ previously used $1.9 \mathrm{~g}$ P4 intravaginal insert during $10 \mathrm{~d}$ alone (UPI) or combined with estradiol benzoate (UPI + EB) or cypionate (UPI + EC) at the removal of UPI. Thirty days later, heifers with a corpus luteum (CL) were treated with $\mathrm{D}$-cloprostenol $\left(\mathrm{PGF}_{2 \alpha}\right)$ and subjected to estrus detection for five days. Heifers were artificially inseminated upon estrous detection. Pregnancy diagnosis was performed $30 \mathrm{~d}$ after by ultrasound. *only when a CL was present at D40; US: ultrasound; BCS: Body condition score.

classified as follows: (1) No change; (2) Low gain (gain of 0.25 of BCS); or (3) High gain (gain of $\geq 0.5$ of BCS).

\subsubsection{Experimental design and ultrasound examination}

On the first day of the trial (Day 0), ovaries were scanned for CL by transrectal ultrasound. Heifers with a CL were excluded from the trial. Heifers without a CL were randomly assigned to one of the four following treatments: Control ( $n=94$; untreated heifers), UPI $[n=130$; insertion of a UPI for $10 \mathrm{~d}$ ], UPI +EB [ $n=128$; similar to UPI plus an i.m. injection of $1 \mathrm{mg}$ EB (Estrogin ${ }^{\circledR}$, Farmavet, São Paulo,
Brazil) at P4 insert removal $]$ and UPI + EC $[n=128$; similar to $\mathrm{UPI}+\mathrm{EB}$ except for replacing EB with $0.5 \mathrm{mg}$ EC i.m. (E.C.P ${ }^{\circledR}$, Zoetis, São Paulo, Brazil)] (Fig. 3). Before insertion, the PI were previously used and washed as described in Exp. 1 . On Day 40, ovaries were scanned by transrectal ultrasound and heifers with a CL received $150 \mu \mathrm{g}$ of D-cloprostenol (Preloban ${ }^{\circledR}$, MSD Animal Health, São Paulo, Brazil). Heifers detected in estrus within the following five days (Days 40-45) were artificially inseminated. Pregnancy diagnosis was performed by transrectal ultrasound $30 \mathrm{~d}$ after the last AI (Day 75).
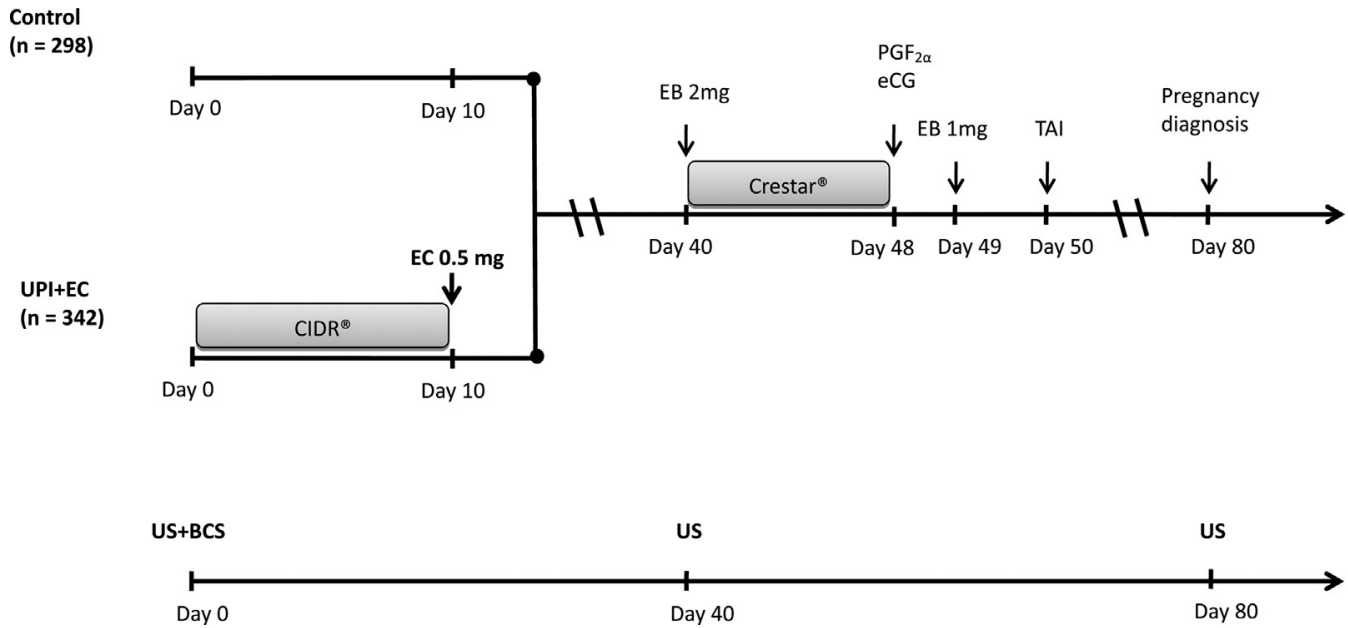

Fig. 4. Design of Experiment 4. Heifers received none (Control), $24 \mathrm{~d}$ previously used $1.9 \mathrm{~g}$ P4 intravaginal insert (UPI) for $10 \mathrm{~d}$ plus estradiol cypionate (EC) at the removalof UPI (UPI + EC). Thirty days later, heifers with a corpus luteum (CL) were subjected to a timed artificial insemination (TAI) protocol (Norgestomet ear implant plus $2 \mathrm{mg}$ EB $-8 \mathrm{~d}-150 \mu \mathrm{g}$ D-cloprostenol $\left(\mathrm{PGF}_{2 \alpha}\right)$ and $300 \mathrm{IU}$ equine chorionic gonadotropin (eCG) - $24 \mathrm{~h}-1 \mathrm{mg}$ EB i.m. $-24 \mathrm{~h}$ - TAI). Pregnancy diagnosis was performed $30 \mathrm{~d}$ after TAI by ultrasound. US: ultrasound; BCS: Body condition score. 


\subsection{Experiment 4: Impact of treatment with P4 and EC prior to TAI}

\subsubsection{Location and animals}

This experiment was conducted on a commercial beef farm located in Rio Verde do MT, Mato Grosso do Sul, Brazil. All heifers grazed on $B$. decumbens pasture with free access to mineral supplement and water. A total of 640 Nelore (B. indicus) beef heifers from 23 to 26 months of age was enrolled in the study. The BCS was recorded on the first day of treatment using a $1-5$ point scale $(1=$ emaciated, 5 = obese) (Ayres et al., 2009).

\subsubsection{Experimental design and ultrasound examination}

On the first day of the trial (Day 0) ovaries were scanned for CL by transrectal ultrasound. Heifers with a CL were excluded from the trial. The remaining heifers $(n=640)$ were randomly assigned to one of the two following treatments: Control $(n=298$; untreated heifers), or UPI+EC $(n=342)$. On Day 0 , heifers from Control group remained untreated, while UPI+EC heifers received a UPI. Before insertion, the PI were previously used and washed as described in Exp. 1. On Day 10, the UPI was removed and $0.5 \mathrm{mg}$ EC i.m. was administered. On Day 40, ovaries were scanned by transrectal ultrasound, and only heifers with a CL were treated with a TAI protocol. The inclusion of only heifers presenting a CL was based on previous data obtained using zebu beef heifers; greater conception rate was expected following the TAI of heifers presenting a CL at beginning of the synchronization of ovulation than non CL heifers (Sá Filho et al., 2010b). The synchronization of ovulation protocol consisted of a NORG ear implant and $2 \mathrm{mg}$ EB i.m. (Day 40). At the implant removal 8 d later (Day 48), all heifers received $150 \mu \mathrm{g}$ D-cloprostenol, 300 IU eCG i.m plus $0.5 \mathrm{mg}$ EC i.m. Two days later (Day 50), all heifers were artificially inseminated at fixed time. Pregnancy diagnosis was performed by transrectal ultrasound $30 \mathrm{~d}$ (Day 80) after TAI (Fig. 4).

\section{Statistical analysis}

In all Exp. (1-4), statistical analyses were performed using the PROC GLIMMIX or MIXED of SAS for Windows (SAS 9.3 Institute Inc., Cary, NC, USA, 2003). Continuous variables were presented as mean \pm standard error of the mean (mean \pm SEM) and percentage (\%) for frequency of occurrence for binomial variables. The continuous response variables were subjected to response scaling test through the solution Guided Data Analysis of SAS. Variables that did not follow these assumptions were transformed accordingly. Binomial variables were analyzed by logistic regression using the SAS GLIMMIX procedure with models fitted to binomial distributions. For the statistical models, variables were removed by Backward Elimination, based on the Wald criterion. Only variables with $P<0.20$ were kept in the final model, unless the variable was essential, such as treatment. Statistical difference was considered when $P \leq 0.05$ and tendency when $P>0.05$ and $\leq 0.10$. Graphs were plotted with Sigmaplot (version 11.0).
In Exp. 1, treatment (Control, PI or UPI) was the independent variable for ovulation rate (\%) and circulating P4 $10 \mathrm{~d}$ after the end of treatment with P4 and E2. All P4 concentrations $(\mathrm{ng} / \mathrm{dL})$ during maintenance of the insert on Days $0,1,4,7$ and 20 were analyzed as repeated measures, using the MIXED procedure of SAS.

In Exp. 2, statistical model was comprised of Farm, Age mo, BCS, Treatment (Control, UPI+EB or EB+UPI+EB), Farm $\times$ Treatment, Treatment $\times$ Age mo and Treatment $\times$ BCS as independent variables, and $\mathrm{CL} /$ Treated and $\mathrm{P} / \mathrm{AI}$ as response variables. An additional analysis was performed considering different BCS $(<3.0$ or $\geq 3.0)$ as independent variables, and $\mathrm{CL} /$ Treated, $\mathrm{P} / \mathrm{AI}$ as response variables.

In Exp. 3, statistical model was comprised of Farm, Treatment (Control, UPI, UPI+EB or UPI+EC), BCS, Age, BCS change, Farm $\times$ Treatment, Treatment $\times$ BCS, Treatment $\times$ Age and Treatment $\times$ BCS change as independent variables, and $\mathrm{CL} /$ Treated, $\mathrm{P} / \mathrm{AI}$ and $\mathrm{P} /$ Treated as response variables. The effect of treatment was also assessed as orthogonal contrast when the objective was to determine differences between females treated or not with PI (C1), effect on animals treated or not with E2 (C2), as well as the effect on animals treated with EB or EC (C3). An additional analysis was done considering different $\mathrm{BCS}(<3.0$ or $\geq 3.0)$ or BCS change [No change, Low $(0.25)$ or High $(\geq 0.5)$ ] as independent variables, and $\mathrm{CL} /$ Treated, $\mathrm{P} / \mathrm{AI}$ and $\mathrm{P} /$ Treated as response variables.

In Exp. 4, the statistical model was comprised of Pen, Treatment (Control or UPI +EC), BCS, Pen $\times$ Treatment and Treatment $\times$ BCS as independent variables, and $C L$ and $\mathrm{P} / \mathrm{AI}$ as response variables. An additional analysis was done considering BCS $(<3.0$ or $\geq 3.0)$ as independent variables, and $\mathrm{CL} /$ Treated, $\mathrm{P} / \mathrm{AI}$ and $\mathrm{P} /$ Treated as response variables.

An additional retrospective analysis, considering heifers enrolled at different trials (Exp. 1-4) was performed to evaluate the impact of treatment on $\mathrm{CL} /$ Treated (All trials; Control $=$ untreated heifers, $n=529$; UPI $=$ all groups that received a P4 stimulus, $n=996$ ), on the P/AI (Exp. 2-4; Control, $n=341$; UPI, $n=767$ ) and on P/Treated heifer (Control, $n=529$; UPI, $n=996$ ). Information from individual heifers from each experiment was collated into a single data set for statistical analysis. Data were analyzed through multivariate logistic regression using the GLIMMIX procedure of SAS. For this analysis, the effect of treatment, BCS class $(\geq 3.0$ or $<3.0$ ) and their interaction were considered as independent variable. The effect of each experiment (1-4) within each farm was considered as a random effect. The response variables evaluated were $\mathrm{CL} /$ Treated, $\mathrm{P} / \mathrm{AI}$ and $\mathrm{P} /$ Treated.

\section{Results}

\subsection{Experiment 1: P4 profile in heifers treated with a P4} insert

Similar BW (325.4 $\pm 8.5,325.3 \pm 7.2$, and $339.1 \pm 9.7 \mathrm{~kg}$; $P>0.05)$ and BCS $(3.2 \pm 0.1, \quad 3.2 \pm 0.1$ and $3.2 \pm 0.1$; $P>0.05$ ) were found among groups (Control, PI and UPI, respectively). The plasma $\mathrm{P} 4$ concentrations during the maintenance of P4 inserts are shown in Fig. 5. Both groups treated with P4 sustained plasma P4 concentration 


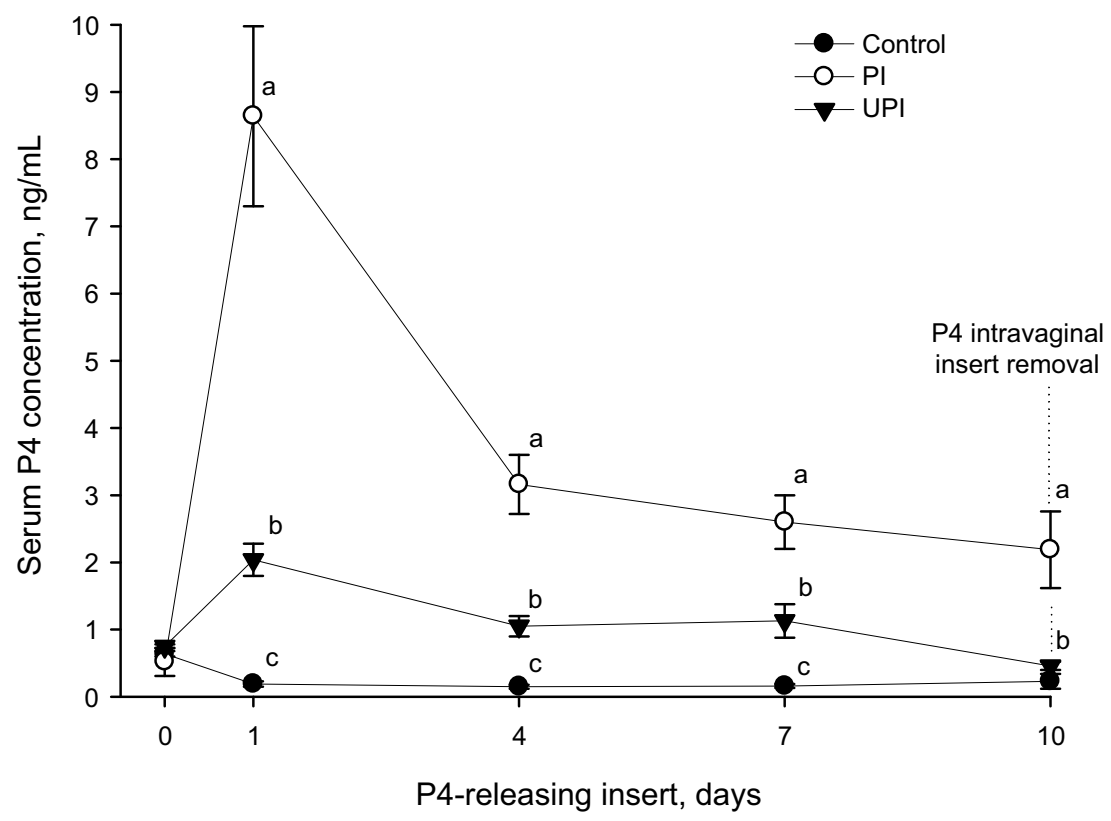

Fig. 5. Plasma progesterone (P4) concentration of prepubertal zebu heifers. Control ( $n=8$; untreated heifers); PI ( $n=10$; insertion of a new P4 insert containing $1.9 \mathrm{~g}$ of P4); and UPI ( $n=9$; insertion of a PI previously used for $24 \mathrm{~d}$ ). After $10 \mathrm{~d}$, the P4 insert was removed in both treatment groups. Treatment $-P<0.01$; Time $-P<0.01$; and Treatment $\times$ Time $-P<0.01$.

above $1 \mathrm{ng} / \mathrm{mL}$ at least during the first $7 \mathrm{~d}$ of the treatment. On Day 20, greater ovulatory response $(P=0.04)$ was observed in heifers treated with $\mathrm{P} 4$ inserts $[\mathrm{PI}=30.0 \%(3 / 10)$ and $\mathrm{UPI}=55.6 \%(5 / 9)]$ than untreated [Control $=0.0 \%(0 / 8)]$. At this moment (Day 20), the plasma P4 concentration was greater $(P<0.0001)$ in UPI treated heifers $(1.38 \pm 0.45 \mathrm{ng} / \mathrm{mL})$ than in Control heifers $(0.18 \pm 0.07 \mathrm{ng} / \mathrm{mL})$. Intermediated concentration of $\mathrm{P} 4$ was found in the PI treated group $(0.83 \pm 0.35 \mathrm{ng} / \mathrm{mL})$.

\subsection{Experiment 2: Combining the use of EB at the beginning and at the end of $P 4$ treatment}

As shown in Table 1, treatment with UPI increased $(P<0.0001)$ the $\mathrm{CL} /$ treated at the onset of the BP (Day $40)$, regardless of the use of EB at the insertion of the PI. Despite the greater number of heifers presenting a CL at beginning of the synchronization of ovulation protocol for $\mathrm{TAI}$, there was no difference between treatments for $\mathrm{P} / \mathrm{AI}$ $(P=0.38)$.

When heifers were classified according to their BCS into two different groups ( $<3.0$ or $\geq 3.0$ ), the presence of a CL at the onset of the BP was lower in poorer $(<3.0)$ BCS heifers than in heifers of BCS $>3.0$ [73.4\% (199/271) vs. $85.5 \%$ (100/117); $P=0.01]$. However, this difference was reversed for P/AI [56.8\% (154/271) vs. 47.9\% (56/117), respectively; $P=0.04)]$.

\subsection{Experiment 3: Using different esters of E2 at the conclusion of $\mathrm{P} 4$ treatment}

Regardless of treatment with E2 at the end of the hormonal therapy (UPI+EB or UPI +EC), the exposure of heifers to exogenous P4 (Control or UPI) influenced the
$\mathrm{CL} /$ treated (orthogonal contrast $-\mathrm{C} 1 ; P=0.005$ ). Furthermore, the administration of an E2 ester (EB or EC) at UPI insert removal tended to an additional effect on $\mathrm{CL} /$ treated (C2; $P=0.10)$. However, there was no difference between both estradiol esters (EB and EC) used (C3; $P=0.30)$. In addition, there was no effect of the exogenous $\mathrm{P} 4$ [Control or UPI $(C 1 ; P=0.54)]$, the administration of an E2 ester at UPI removal $(\mathrm{C} 2 ; \mathrm{P}=0.73)$ on the $\mathrm{P} / \mathrm{AI}$. However, EC-treated heifers presented greater $\mathrm{P} / \mathrm{AI}$ than EB-treated heifers ( $\mathrm{C} 3$; $P=0.04)$. The exposure of heifers to exogenous $\mathrm{P} 4$ promoted greater $\mathrm{P} /$ Treated $(\mathrm{C} 1 ; P=0.02)$. Such difference was not maintained following the administration of E2 ester at UPI removal ( $C 2 ; P=0.41)$. However, heifers treated with EC presented greater $\mathrm{P} /$ Treated than those treated with $\mathrm{EB}$ at $i \mathrm{P} 4$ removal $(\mathrm{C} 3 ; \mathrm{P}=0.04)$.

BCS had a positive effect on CL/Treated at the onset of the BP $[<3.0=51.2 \%(169 / 330) v s$. $\geq 3.0=76.7 \%$ (115/150); $P<0.0001]$. This effect was also observed on P/AI $[<3.0=51.0 \%(74 / 145)$ vs. $\geq 3.0=58.7 \%(64 / 109) ; P=0.04]$ and on $\mathrm{P} /$ Treated $[<3.0=22.4 \%(74 / 330) v s$. $\geq 3.0=42.7 \%$ (64/150); $P<0.0001]$. This finding was supported by the analysis of the effect of BCS change [No change, Low gain $(0.25)$ or High gain $(\geq 0.5)$ ] on $C L /$ Treated, P/AI and $\mathrm{P} /$ Treated. Greater outcomes were observed as the heifers moved from stable BCS to gaining $\geq 0.5$ points of score. The CL/Treated at onset of BP had an increase of almost $40 \%$ when heifers gained $\geq 0.5$ points of BCS compared to those which sustained stable BCS [No change $=49.0 \%$ $(24 / 49)^{\mathrm{b}}$, Low $=53.8 \%(120 / 223)^{\mathrm{b}}$, High $=67.3 \%(140 / 208)^{\mathrm{a}}$; $P<0.0001$ ]. Similarly, greater P/AI [No change $=40.9 \%$ $(9 / 22)^{\mathrm{b}}$, Low $=53.8 \%(56 / 104)^{\mathrm{ab}}$, High $=57.0 \%(73 / 128)^{\mathrm{a}}$; $P=0.05$ ] and greater $P /$ Treated [No change $=18.4 \%(9 / 49)^{\mathrm{b}}$, Low $=25.1 \%(56 / 223)^{\mathrm{b}}$, High $\left.=35.1 \%(73 / 208)^{\mathrm{a}} ; P<0.0001\right]$ was observed as gain in BCS improved. 
Table 1

General results from Exp. 2-4.

\begin{tabular}{|c|c|c|c|c|c|c|c|c|c|}
\hline \multirow[t]{2}{*}{ Item } & \multicolumn{3}{|l|}{ CL/Treated ${ }^{\mathrm{a}}$} & \multicolumn{3}{|l|}{$\mathrm{P} / \mathrm{AI}^{\mathrm{b}}$} & \multicolumn{3}{|l|}{ P/Treated ${ }^{\mathrm{C}}$} \\
\hline & $\%(n / n)$ & Odds ratio $(\mathrm{CI})$ & $P$ value & $\%(n / n)$ & Odds ratio $(\mathrm{CI})$ & $P$ value & $\%(n / n)$ & Odds ratio $(\mathrm{CI})$ & $P$ value \\
\hline \multicolumn{10}{|l|}{ Experiment 2} \\
\hline \multicolumn{10}{|l|}{ Treatments ${ }^{\mathrm{d}}$} \\
\hline Control & $60.3(78 / 129)^{b}$ & Reference & \multirow{3}{*}{$<0.0001$} & $49.6(64 / 129)$ & Reference & \multirow{3}{*}{0.38} & $49.6(64 / 129)$ & Reference & \multirow{3}{*}{0.38} \\
\hline $\mathrm{UPI}+\mathrm{EB}$ & $85.3(114 / 134)^{a}$ & $3.8(2.0-7.1)$ & & $57.5(77 / 134)$ & $1.4(0.8-2.3)$ & & $57.5(77 / 134)$ & $1.4(0.8-2.3)$ & \\
\hline $\mathrm{EB}+\mathrm{UPI}+\mathrm{EB}$ & $80.8(101 / 125)^{a}$ & $2.7(1.5-5.0)$ & & $55.2(69 / 125)$ & $1.3(0.8-2.1)$ & & $55.2(69 / 125)$ & $1.3(0.8-2.1)$ & \\
\hline \multicolumn{10}{|l|}{ Experiment 3} \\
\hline \multicolumn{10}{|l|}{ Treatments } \\
\hline Control & $42.5(40 / 94)^{c}$ & Reference & \multirow{4}{*}{0.01} & $61.3(19 / 31)$ & Reference & \multirow{4}{*}{0.21} & $20.2(19 / 94)^{\mathrm{b}}$ & Reference & \multirow{4}{*}{0.02} \\
\hline UPI & $58.5(76 / 130)^{\mathrm{bc}}$ & $1.3(0.7-2.4)$ & & $54.3(38 / 70)$ & $1.2(0.4-3.2)$ & & $29.2(38 / 130)^{a b}$ & $1.8(0.9-3.7)$ & \\
\hline $\mathrm{UPI}+\mathrm{EB}$ & $64.0(82 / 128)^{\mathrm{ab}}$ & $1.9(1.0-3.5)$ & & $45.3(34 / 75)$ & $0.9(0.3-2.5)$ & & $26.6(34 / 128)^{\mathrm{b}}$ & $1.7(0.8-3.4)$ & \\
\hline $\mathrm{UPI}+\mathrm{EC}$ & $67.2(86 / 128)^{a}$ & $2.5(1.3-4.7)$ & & $60.3(47 / 78)$ & $1.9(0.7-5.1)$ & & $36.7(47 / 128)^{a}$ & $3.0(1.5-6.0)$ & \\
\hline \multicolumn{10}{|l|}{ Experiment 4} \\
\hline \multicolumn{10}{|l|}{ Treatments ${ }^{\mathrm{f}}$} \\
\hline Control & $60.7(181 / 298)$ & Reference & \multirow{2}{*}{$<0.0001$} & $43.6(79 / 181)$ & Reference & \multirow{2}{*}{0.08} & $26.5(79 / 298)$ & Reference & \multirow{2}{*}{$<0.0001$} \\
\hline $\mathrm{UPI}+\mathrm{EC}$ & $83.3(285 / 342)$ & $3.7(2.4-5.7)$ & & $51.9(148 / 285)$ & $1.4(0.9-2.0)$ & & $43.3(148 / 342)$ & $2.0(1.5-2.9)$ & \\
\hline \multicolumn{10}{|c|}{ a $\mathrm{CL} /$ Treated: percentage of heifers presenting corpus luteum (CL) 30 days after used progesterone (P4) insert (UPI) removal. } \\
\hline \multicolumn{10}{|c|}{ b Pregnancy per artificial insemination $(\mathrm{P} / \mathrm{AI})$. } \\
\hline \multicolumn{10}{|c|}{ c Pregnancy per treated heifer (P/Treated). } \\
\hline \multicolumn{10}{|c|}{ d Treatments of Exp. 2: Heifers received none ( } \\
\hline \\
\hline \multicolumn{10}{|c|}{ e Treatments of Exp. 3: Heifers received none (Control), a UPI alone (UPI) or combined with estradiol benzoate (UPI + EB) or estradiol cypionate (UPI + EC) } \\
\hline \multicolumn{10}{|c|}{ at the end of P4 treatment. } \\
\hline \multicolumn{10}{|c|}{ f Treatments of Exp. 4: Heifers received none (Control) or a UPI combined with estradiol cypionate (UPI + EC) at the end of P4 treatment. } \\
\hline
\end{tabular}

\subsection{Experiment 4: Impact of treatment with P4 and EC} prior to TAI

As shown in Table 1 , control untreated heifers had lower $\mathrm{CL} /$ Treated $(P<0.0001)$, tended to present lower P/AI $(P=0.08)$ and had lower $P /$ Treated $(P<0.0001)$ than UPI + EC treated heifers. When heifers were analyzed according to their BCS $(<3.0 v s . \geq 3.0)$, those with greater BCS had similar CL/Treated at the beginning of the BP [96.4\% (27/28) vs. 71.7\% (439/612); $P=0.39], \mathrm{P} / \mathrm{AI}[48.2 \%$ (13/27) vs. $48.8 \%$ (214/439); $P=0.94]$ and $P /$ Treated $[46.4 \%$ (13/28) vs. $35.0 \%$ $(214 / 612) ; P=0.85]$ than the ones with lesser BCS.

\subsection{Retrospective analysis}

Considering the retrospective analysis, treatments with UPI plus E2 were efficient in increasing the $\mathrm{CL} /$ treated at the onset of the BP $(P<0.0001)$, enhanced $\mathrm{P} / \mathrm{AI}(P=0.04)$ and $P /$ Treated $(P<0.0001)$ (Fig. 6). When the BCS analysis was performed, $C L /$ Treated was greater $(P<0.0001)$ in heifers presenting $\mathrm{BCS} \geq 3.0$ (74.0\%; 657/888) than those with BCS $<3.0(62.3 \% ; 397 / 637)$. Such difference was not sustained regarding $\mathrm{P} / \mathrm{AI}[\mathrm{BCS} \geq 3.0=50.2 \%(334 / 665)$ vs. $\mathrm{BCS}<3.0=54.4 \%(241 / 443) ; \quad P=0.45]$ or $\mathrm{P} /$ Treated $[\mathrm{BCS} \geq 3.0=37.6 \%(334 / 888) v s . \mathrm{BCS}<3.0=37.8 \%(241 / 63)$; $P=0.25]$.

\section{Discussion}

This sequence of trials demonstrated that treatment with a UPI combined with the administration of E2 is efficient to increase the number of beef heifers with a CL at the onset of the BP. The PI was capable of sustaining the plasma $\mathrm{P} 4$ concentration above $1 \mathrm{ng} / \mathrm{mL}$ at least during the first $7 \mathrm{~d}$ of the $10-\mathrm{d}$ treatment period. Also, this hormonal therapy demonstrated the importance of associating an E2 ester at the UPI removal by improving the $\mathrm{CL} /$ treated (EB or EC) and enhancing the P/treated (mainly for EC-treated heifers). Nonetheless, the additional treatment with EB at the insertion of the UPI did not improve the ovulatory response of treated heifers (Exp. 2). Besides increasing the $\mathrm{CL} /$ treated at the beginning of the TAI protocol, UPI + EC treated heifers also had greater P/AI and $\mathrm{P} /$ Treated, supporting the initial hypothesis of the present experiments.

The beneficial effects of P4 on hastening puberty were previously described in both $B$. taurus (Anderson et al., 1996; Gonzalez-Padilla et al., 1975), B. taurus $\times$ B. indicus (Rasby et al., 1998) and B. indicus (Claro et al., 2010; Rodrigues et al., 2013) prepubertal heifers. In the first trial described herein, the efficiency of new or 24-d-used $1.9 \mathrm{~g}$ PI was demonstrated. The UPI sustained the plasma P4 concentration $>1 \mathrm{ng} / \mathrm{mL}$ at least during the first $7 \mathrm{~d}$ of the treatment and improved the ovulation rate after treatment. However, new inserts sustained greater plasma P4 concentrations. In fact, it is known that an excessive circulating P4 concentration particularly during the final dominant follicle growth could harm the ovulatory capacity and/or lead to the ovulation of smaller follicles which secrete less P4 (Adams et al., 1992; Carvalho et al., 2008; Dias et al., 2009; Mantovani et al., 2010; Sá Filho et al., 2010a). Conversely, a low P4 concentration during the synchronization protocol promoted increased follicular growth rate resulting in a larger diameter ovulatory follicle with greater ovulatory capacity (Dadarwal et al., 2013; Mantovani et al., 2010). Likewise, specifically in prepubertal beef heifers, greater reproductive performance was achieved when zebu heifers were treated with a UPI rather than a new one (Claro et al., 2010). Therefore, it seems that the quantity of P4 released by a UPI is enough to control follicular growth of zebu 


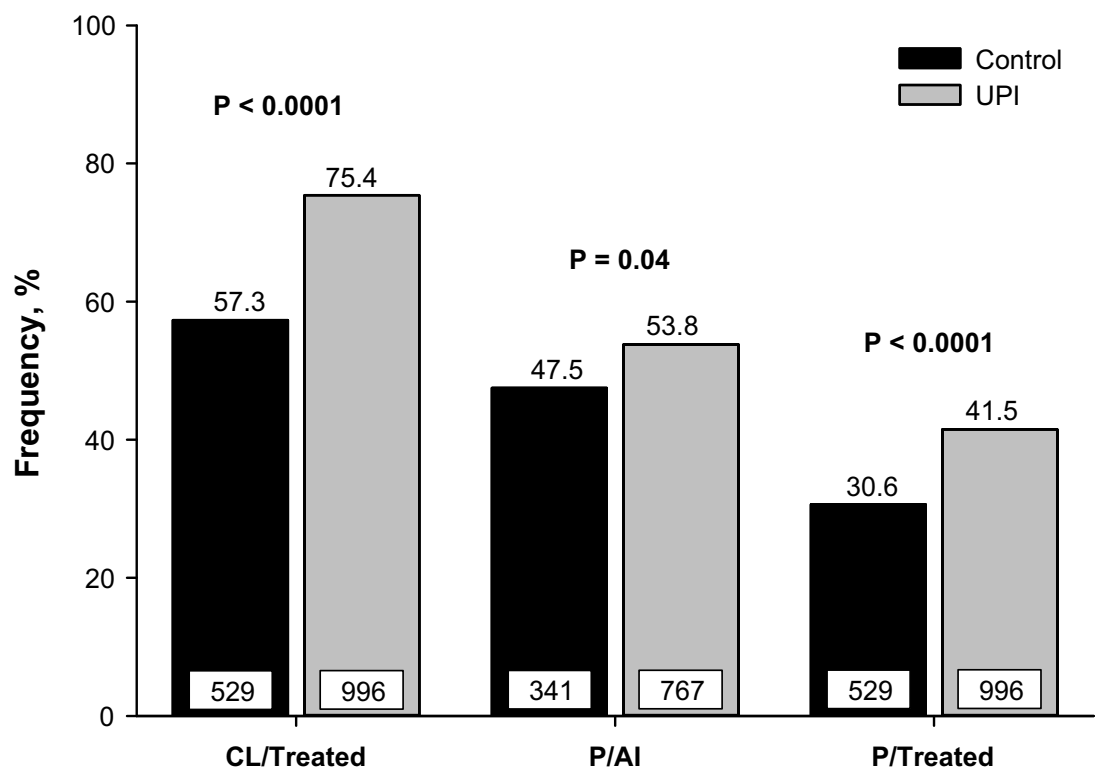

Fig. 6. Retrospective analysis of heifers in all experiments. CL/Treated: heifers (\%) presenting a corpus luteum (CL) 30 days after used progesterone (P4) insert (UPI) removal ( $n=1525$; Control = untreated heifers, $\mathrm{UPI}=$ all groups receiving a $\mathrm{P} 4$ stimulus prior to the breeding period). Pregnancy per $\mathrm{AI}(\mathrm{P} / \mathrm{AI})$ considering just the heifers that were artificially inseminated $(n=1108)$ and pregnancy per total of treated heifers $(\mathrm{P} /$ Treated $)$, considering all heifers in all trials $(n=1525)$.

prepubertal beef heifers, improving ovulation response with a potential positive effect on subsequent reproductive performance.

The E2 negative feedback on GnRH secretion is a determining factor on the occurrence of first ovulation in heifers. Furthermore, the use of exogenous P4 (Anderson et al., 1996; Rasby et al., 1998) and the increase of endogenous E2 has been described to turn this feedback to become more positive, culminating in ovulation (Day, 1987; Nogueira, 2004; Rasby et al., 1998). Similar to the results described here, a positive effect of the treatment associating exogenous P4 exposure plus an E2 stimulus at the P4 insert removal, increasing the amount of beef zebu heifers with a $\mathrm{CL}$ at the beginning of the BP has been described by other authors (Rodrigues et al., 2014). However, the administration of additional E2 stimulus at the insertion of the UPI did not enhance $\mathrm{CL} /$ Treated or P/AI in the current study. These findings indicate that increasing the concentration of estradiol at the end of the P4-based protocol is sufficient to simulate physiological proestrus and to trigger ovulation in B. indicus heifers. Besides that, without the induction of follicular wave emergence by E2 stimulus at the insertion of the UPI, the development of a persistent follicle will be stimulated (Mantovani et al., 2005). This follicle has a detrimental effect on conception rate after artificial insemination because of an altered oviductal environment (Binelli et al., 1999), premature maturation of the oocyte (Revah and Butler, 1996), or both. However, this would not necessarily be detrimental for the present hormonal strategy, because the heifers will be exposed to at least one estrous cycle before initiation of breeding, which ensures that this potential low fertility estrus does not become a factor.
In Exp. 3, similar response were found on CL/Treated after the treatment according to the ester of estradiol (EC or EB) used at the end of the hormonal therapy; however heifers treated with EC presented greater P/AI and $\mathrm{P} /$ treated. The EC and EB have distinguished chemical structures and estradiol-17 $\beta$ releasing profiles (Souza et al., 2005); however, both are equally capable of inducing a pre-ovulatory LH surge (Sales et al., 2012) and efficient at inducing ovulation in lactating zebu cows (Torres et al., 2014) and in cyclic zebu heifers (Sá Filho et al., 2011a) subjected to TAI protocol. The distinct pharmacokinects of both esters causes prolonged biological activity of EC (Vynckier et al., 1990) but smaller peak of plasma estradiol concentration (Martínez et al., 2005) in comparison to EB. This might result in a better uterine modulation and different subsequent luteal activity (Perry and Perry, 2008; Sá Filho et al., 2011b), which could explain the greater P/AI, and consequently, greater P/treated of UPI + EC treated heifers. Thus, despite of similar CL/treated between different estradiol esters administrated at P4 insert removal, the EC could be considered the elective drug to treat zebu beef heifers before the onset of the BP.

In Exp. 4, the 10-d treatment with UPI associated with EC increased the $\mathrm{CL} /$ treated and tended to improve the P/AI and, consequently enhanced the $\mathrm{P} /$ Treated. Previous studies have also shown improved conception rates for cyclic heifers early in the BP (Claro et al., 2010; Rodrigues et al., 2013). When more heifers conceive early in the BP the chance they will be pregnant in the subsequent $\mathrm{BP}$ is greater and the risk of involuntary culling is lower (Cushman et al., 2013; Gonzalez-Padilla et al., 1975; Rhodes et al., 2003). Therefore, the routine use of P4 plus EC hormonal therapy prior to the onset of the BP could be considered as an 
important reproductive strategy to improve the reproductive efficiency of zebu beef heifers.

The efficiency of the hormonal protocol to increase the $\mathrm{CL} /$ Treated at the onset of the BP was clearly observed in all experiments as well as in the retrospective analysis. Interestingly, $\mathrm{P} / \mathrm{AI}$ did not improve in experiments 2 and 3; however, it tended to improve in experiment 4 and was statistically different in the retrospective analysis. Therefore, beef heifers treated with P4 and E2 before the BP presented greater ovulatory response, possibly due to the modulation of their hypothalamus, increasing GnRH secretion (Day, 1987; Graden et al., 1968; Yavas and Walton, 2000). However, impact on P/AI could be affected by other important risk factors such as percentage of mature body weight at breeding, body weight changes from beginning of treatment to TAI or number of consecutive luteal phases prior to AI (Byerley and Staigmiller, 1987; Funston and Deutscher, 2004; Gasser et al., 2006).

In all trials, heifers presenting greater BCS $(\geq 3.0)$ had greater occurrence of CL at the onset of the BP. Also, greater outcomes ( $\mathrm{CL} /$ Treated, $\mathrm{P} / \mathrm{AI}$ and $\mathrm{P} /$ treated) were observed as the heifers moved from stable BCS to gaining $\geq 0.25$ points of score (Exp. 3). The effect of BCS on fertility of beef cows following AI programs and throughout of breeding season is well known (Ayres et al., 2014; Randel, 1990) and physiological associations in both cows and heifers are well documented (Day and Maquivar, 2014; Funston et al., 2012b; Romano et al., 2007). However, the positive impact of greater body energy reserves on P/IA was not on the Exp. 4. In accordance with our results, lack of BCS effect on P/AI has also been reported in B. taurus beef heifers synchronized with five-day CO-Synch plus $i \mathrm{P} 4$ protocol (Kasimanickam et al., 2015, 2012), B. indicus $\times$ B. taurus heifers subjected to progestogen-based estrous synchronization protocols (McKinniss et al., 2011) and in B. indicus heifers subjected to an E2 + P4 based TAI protocol (Butler et al., 2011). In addition, the absence of BCS effect on P/AI found in the present could be underscored by the selection criteria applied in Exp. 4, which only heifers presenting a CL were subjected to TAI. Therefore, the metabolic status of the heifer, as evidenced by the BCS, apparently presents major impact on the advent of puberty (Day and Maquivar, 2014) and minor influence on P/AI, mainly those heifers presenting a CL at onset of TAI synchronization protocol. However, the mechanism whereby nutrition influences $\mathrm{P} / \mathrm{AI}$ in heifers subjected to TAI programs requires further controlled investigations.

In conclusion, treatment with an UPI sustained a plasma P4 concentration above $1 \mathrm{ng} / \mathrm{mL}$ at least during the first $7 \mathrm{~d}$ of the 10-d treatment period (Exp. 1). The use of an additional dose of EB at the beginning of the hormonal protocol did not increase the CL/Treated or P/AI (Exp. 2). The $\mathrm{CL} /$ Treated tended to be improved when an estradiol ester is used at UPI removal, regardless of the ester (EB or EC; Exp. 3). However, greater P/AI and P/Treated were achieved when EC was administrated at UPI removal in comparison to EB (Exp. 3). A protocol associating P4 plus EC at P4 removal increases the $\mathrm{CL} /$ Treated at the beginning of the $\mathrm{BP}$, tends to improve P/AI and enhances the P/Treated (Exp. 4). As to the retrospective analysis, the treatment associating P4 plus E2 before the onset of the BP increased the number of heifers with a $\mathrm{CL}$, the $\mathrm{P} / \mathrm{AI}$ and consequently the $\mathrm{P} /$ Treated.

\section{Acknowledgements}

The authors would like to thank Grupo Pennacchi Silvipastoril (Cascavel - PR) and Grupo Piveta (Rio Verde do MT - MS) farms for allowing the use of their heifers and facilities during the trial. These experiments were supported by Firmasa-Pecuária com Tecnologia and Geraembryo. The authors also would like to thank Zoetis for donation of hormones and P4 measurement kits (Experiment 1).

\section{References}

Adams, G.P., Matteri, R.L., Ginther, O.J., 1992. Effect of progesterone on ovarian follicles, emergence of follicular waves and circulating follicle-stimulating hormone in heifers. J. Reprod. Fertil. 96, 627-640.

Anderson, L.H., Mcdowell, C.M., Day, M.L., Al, A.E.T., 1996. Progestin-induced puberty and secretion of luteinizing hormone in heifers'. Biol. Reprod. 1031, 1025-1031.

Ayres, H., Ferreira, R.M., de Souza Torres-Júnior, J.R., Demétrio, C.G.B., de Lima, C.G., Baruselli, P.S., 2009. Validation of body condition score as a predictor of subcutaneous fat in Nelore (Bos indicus) cows. Livest. Sci. 123, 175-179, http://dx.doi.org/10.1016/j.livsci.2008.11.004.

Ayres, H., Ferreira, R.M., Torres-Júnior, J.R.S., Demétrio, C.G.B., Sá Filho, M.F., Gimenes, L.U., Penteado, L., D’Occhio, M.J., Baruselli, P.S., 2014. Inferences of body energy reserves on conception rate of suckled Zebu beef cows subjected to timed artificial insemination followed by natural mating. Theriogenology $82,529-536$, http://dx.doi.org/10.1016/j.theriogenology.2014.04.026.

Binelli, M., Hampton, J., Buhi, W.C., Tatcher, W.W., 1999. Persistent dominant follicle alters pattern of oviductal secretory proteins from cows at estrus. Biol. Reprod. 61, 127-134, http://dx.doi.org/10.1095/biolreprod61.1.127.

Butler, S.A.A., Atkinson, P.C., Boe-Hansen, G.B., Burns, B.M., Dawson, K., Bo, G.A., McGowan, M.R., 2011. Pregnancy rates after fixed-time artificial insemination of Brahman heifers treated to synchronize ovulation with low-dose intravaginal progesterone releasing devices, with or without eCG. Theriogenology 76, 1416-1423, http://dx.doi.org/10.1016/j.theriogenology.2011.06.010.

Byerley, D., Staigmiller, R., 1987. Pregnancy rates of beef heifers bred either on puberal or third estrus. J. Anim. Sci. 65, 645-650.

Carvalho, J.B.P., Carvalho, N.A.T., Reis, E.L., Nichi, M., Souza, A.H., Baruselli, P.S., 2008. Effect of early luteolysis in progesterone-based timed AI protocols in Bos indicus, Bos indicus $\times$ Bos taurus, and Bos taurus heifers. Theriogenology 69, 167-175, http://dx.doi.org/10.1016/j.theriogenology.2007.08.035.

Claro, I., Sá Filho, O.G., Peres, R.F.G., Aono, F.H.S., Day, M.L., Vasconcelos, J.L.M., 2010. Reproductive performance of prepubertal Bos indicus heifers after progesterone-based treatments. Theriogenology 74 , 903-911, http://dx.doi.org/10.1016/j.theriogenology.2010.04.015.

Cushman, R.A., Kill, L.K., Funston, R.N., Mousel, E.M., Perry, G.A., 2013. Heifer calving date positively influences calf weaning weights through six parturitions. J. Anim. Sci. 91, 4486-4491, http://dx.doi.org/10.2527/jas.2013-6465.

Dadarwal, D., Mapletoft, R.J., Adams, G.P., Pfeifer, L.F.M., Creelman, C., Singh, J., 2013. Effect of progesterone concentration and duration of proestrus on fertility in beef cattle after fixed-time artificial insemination. Theriogenology 79, 859-866, http://dx.doi.org/10.1016/j.theriogenology.2013.01.003.

Day, M.L., 1987. Endocrine mechanisms of puberty in heifers. Role of hypothalamo-pituitary estradiol receptors in the negative feedback of estradiol on luteinizing hormone secretion. Biol. Reprod. 37, 1054-1065, http://dx.doi.org/10.1095/biolreprod37.5.1054.

Day, M.L., Maquivar, M., 2014. Puberty in heifers: nutrition and endocrinology. In: Proc. AETA Jt. Annu. Conv.

Dias, C.C., Wechsler, F.S., Day, M.L., Vasconcelos, J.L.M., 2009. Progesterone concentrations, exogenous equine chorionic gonadotropin, and timing of prostaglandin $\mathrm{F}$ (2alpha) treatment affect fertility in postpuberal Nelore heifers. Theriogenology 72 , 378-385, http://dx.doi.org/10.1016/j.theriogenology.2009.03.006.

Eler, J.P., Silva, J.A.I.I.V., Ferraz, J.B.S., Dias, F., Oliveira, H.N., Evans, J.L., Golden, B.L., 2002. Genetic evaluation of the probability of pregnancy 
at 14 months for Nellore heifers. J. Anim. Sci. 80, 951-954, doi:/2002.804951x

Ferrell, C.L., 1982. Effects of postweaning rate of gain on onset of puberty and productive performance of heifers of different breeds. J. Anim. Sci. 55, 1272-1283.

Funston, R.N., Deutscher, G.H., 2004. Comparison of target breeding weight and breeding date for replacement beef heifers and effects on subsequent reproduction and calf performance. J. Anim. Sci. 82, 3094-3099.

Funston, R.N., Musgrave, J.A., Meyer, T.L., Larson, D.M., 2012a. Effect of calving distribution on beef cattle progeny performance. J. Anim. Sci. 90, 5118-5121, http://dx.doi.org/10.2527/jas.2012-5263.

Funston, R.N., Summers, A.F., Roberts, A.J., 2012b. Alpharma Beef Cattle Nutrition Symposium: implications of nutritional management for beef cow-calf systems. J. Anim. Sci. 90, 2301-2307, http://dx.doi.org/10.2527/jas.2011-4568.

Gasser, C.L., Behlke, E.J., Grum, D.E., Day, M.L., 2006. Effect of timing of feeding a high-concentrate diet on growth and attainment of puberty in early-weaned heifers. J. Anim. Sci. 84, 3118-3122, http://dx.doi.org/10.2527/jas.2005-676.

Gonzalez-Padilla, E., Ruiz, R., LeFever, D., Denham, A., Wiltbank, J.N. 1975. Puberty in beef heifers. III. Induction of fertile estrus. J. Anim. Sci. 40, 1110-1118.

Graden, A.P., Olds, D., Mochow, C.R., Mutter, L.R., 1968. Causes of fertilization failure in repeat breeding cattle. J. Dairy Sci. 51, 778-781, http://dx.doi.org/10.3168/jds.S0022-0302(68)87070-5.

Grings, E.E., Hall, J.B., Bellows, R.A., Short, R.E., Bellows, S.E., Staigmiller, R.B., 1998. Effect of nutritional management, trace mineral supplementation, and norgestomet implant on attainment of puberty in beef heifers. J. Anim. Sci. 76, 2177-2181.

Hall, J.B., Staigmiller, R.B., Short, R.E., Bellows, R.A., MacNeil, M.D., Bellows, S.E., 1997. Effect of age and pattern of gain on induction of puberty with a progestin in beef heifers. J. Anim. Sci. 75, 1606-1611.

Imwalle, D.B., Patterson, D.J., Schillo, K.K., 1998. Effects of melengestrol acetate on onset of puberty, follicular growth, and patterns of luteinizing hormone secretion in beef heifers. Biol. Reprod. 58 1432-1436, http://dx.doi.org/10.1095/biolreprod58.6.1432.

Kasimanickam, R., Asay, M., Firth, P., Whittier, W.D., Hall, J.B., 2012. Artificial insemination at $56 \mathrm{~h}$ after intravaginal progesterone device removal improved AI pregnancy rate in beef heifers synchronized with five-day CO-Synch + controlled internal drug release (CIDR) protocol. Theriogenology 77, 1624-1631,

http://dx.doi.org/10.1016/j.theriogenology.2011.12.007.

Kasimanickam, R., Schroeder, S., Hall, J.B., Whittier, W.D., 2015. Fertility after implementation of long- and short-term progesterone-based ovulation synchronization protocols for fixed-time artificial insemination in beef heifers. Theriogenology 83, 1226-1232 http://dx.doi.org/10.1016/j.theriogenology.2015.01.004.

Mantovani, a, P., Reis, E.L., Gacek, F., Bó, G.A., Binelli, M., Baruselli, P.S., 2005. Prolonged use of a progesterone-releasing intravaginal device $\left(\mathrm{CIDR}^{\circledR}\right)$ for induction of persistent follicles in bovine embryo recipients. Anim. Reprod. 2, 272-277.

Mantovani, A.P., Nichi, M., Filho, M.F.S., Ayres, H., Vettorato, L.F., Bo, G.a, Baruselli, P.S., 2010. Follicular growth and plasma progesterone patterns in Bos indicus $\times$ Bos taurus heifers submitted to different PGF2 $\alpha /$ progesterone-based synchronization protocols. Anim. Reprod. 7, 91-96.

Martínez, M.F., Kastelic, J.P., Bó, G.A., Caccia, M., Mapletoft, R.J., 2005. Effects of oestradiol and some of its esters on gonadotrophin release and ovarian follicular dynamics in CIDR-treated beef cattle. Anim. Reprod. Sci. 86, 37-52, http://dx.doi.org/10.1016/j.anireprosci.2004.06.005.

McKinniss, E.N., Esterman, R.D., Woodall, S.A., Austin, B.R., Hersom, M.J., Thatcher, W.W., Yelich, J.V., 2011. Evaluation of two progestogen-based estrous synchronization protocols in yearling heifers of Bos indicus $\times$ Bos taurus breeding. Theriogenology 75 1699-1707, http://dx.doi.org/10.1016/j.theriogenology.2011.01.007.

Nogueira, G.P., 2004. Puberty in South American Bos indicus (Zebu) cattle. Anim. Reprod. Sci. 82-83, 361-372, http://dx.doi.org/10.1016/j.anireprosci.2004.04.007.

Patterson, D.J., Perry, R.C., Kiracofe, G.H., Bellows, R.A., Staigmiller, R.B., Corah, L.R., 1992. Management considerations in heifer development and puberty. J. Anim. Sci. 70, 4018-4035.

Perry, G.A., Perry, B.L., 2008. Effect of preovulatory concentrations of estradiol and initiation of standing estrus on uterine $\mathrm{pH}$ in beef cows. Domest. Anim. Endocrinol. 34, 333-338, http://dx.doi.org/10.1016/j.domaniend.2007.09.003.
Randel, R.D., 1990. Nutrition and postpartum rebreeding in cattle. J. Anim. Sci. 68, 853-862, doi:/1990.683853x

Rasby, R., Day, M., Johnson, S., Kinder, J., Lynch, J., Short, R., Wettemann, R., Hafs, H., 1998. Luteal function and estrus in peripubertal beef heifers treated with an intravaginal progesterone releasing device with or without a subsequent injection of estradiol. Theriogenology 50, 55-63, http://dx.doi.org/10.1016/S0093-691X(98)00113-7.

Revah, I., Butler, W.R., 1996. Prolonged dominance of follicles and reduced viability of bovine oocytes. Reproduction 106, 39-47, http://dx.doi.org/10.1530/jrf.0.1060039.

Rhodes, F.M., McDougall, S., Burke, C.R., Verkerk, G.A., Macmillan, K.L. 2003. Invited review: treatment of cows with an extended postpartum anestrous interval. J. Dairy Sci. 86, 1876-1894 http://dx.doi.org/10.3168/jds.S0022-0302(03)73775-8.

Rodrigues, A.D.P., Peres, R.F.G., Lemes, A.P., Martins, T., Pereira, M.H.C., Carvalho, E.R., Day, M.L., Vasconcelos, J.L.M., 2014. Effect of interval from induction of puberty to initiation of a timed AI protocol on pregnancy rate in Nellore heifers. Theriogenology 82, 760-766, http://dx.doi.org/10.1016/j.theriogenology.2014.06.008.

Rodrigues, A.D.P., Peres, R.F.G., Lemes, A.P., Martins, T., Pereira, M.H.C., Day, M.L., Vasconcelos, J.L.M., 2013. Progesterone-based strategies to induce ovulation in prepubertal Nellore heifers. Theriogenology 79, 135-141, http://dx.doi.org/10.1016/j.theriogenology.2012.09.018.

Romano, M.A., Barnabe, V.H., Kastelic, J.P., de Oliveira, C.A., Romano, R.M., 2007. Follicular dynamics in heifers during pre-pubertal and pubertal period kept under two levels of dietary energy intake. Reprod. Domest. Anim. 42, 616-622, http://dx.doi.org/10.1111/j.1439-0531.2006.00832.x.

Sá Filho, M.F., Baldrighi, J.M., Sales, J.N.S., Crepaldi, G.A., Carvalho, J.B.P. Bó, G.A., Baruselli, P.S., 2011a. Induction of ovarian follicular wave emergence and ovulation in progestin-based timed artificial insemination protocols for Bos indicus cattle. Anim. Reprod. Sci. 129, 132-139, http://dx.doi.org/10.1016/j.anireprosci.2011.12.005.

Sá Filho, M.F., Crespilho, A.M., Santos, J.E.P., Perry, G.A., Baruselli, P.S., 2010a. Ovarian follicle diameter at timed insemination and estrous response influence likelihood of ovulation and pregnancy after estrous synchronization with progesterone or progestin-based protocols in suckled Bos indicus cows. Anim. Reprod. Sci. 120, 23-30, http://dx.doi.org/10.1016/j.anireprosci.2010.03.007.

Sá Filho, M.F., Santos, J.E.P., Ferreira, R.M., Sales, J.N.S., Baruselli, P.S., 2011b. Importance of estrus on pregnancy per insemination in suckled Bos indicus cows submitted to estradiol/progesterone-based timed insemination protocols. Theriogenology 76, 455-463, http://dx.doi.org/10.1016/j.theriogenology.2011.02.022.

Sá Filho, M.F., Torres-Júnior, J.R.S., Penteado, L., Gimenes, L.U., Ferreira, R.M., Ayres, H., Castro, E., Paula, L.A., Sales, J.N.S., Baruselli, P.S. 2010 b. Equine chorionic gonadotropin improves the efficacy of a progestin-based fixed-time artificial insemination protocol in Nelore (Bos indicus) heifers. Anim. Reprod. Sci. 118, 182-187, http://dx.doi.org/10.1016/j.anireprosci.2009.10.004.

Sales, J.N.S., Carvalho, J.B.P., Crepaldi, G.A., Cipriano, R.S., Jacomini, J.O., Maio, J.R.G., Souza, J.C., Nogueira, G.P., Baruselli, P.S., 2012. Effects of two estradiol esters (benzoate and cypionate) on the induction of synchronized ovulations in Bos indicus cows submitted to a timed artificial insemination protocol. Theriogenology 78, 510-516, http://dx.doi.org/10.1016/j.theriogenology.2012.02.031.

Sartori, R., Bastos, M.R., Baruselli, P.S., Gimenes, L.U., Ereno, R.L., Barros, C.M., 2010. Physiological differences and implications to reproductive management of Bos taurus and Bos indicus cattle in a tropical environment. Soc. Reprod. Fertil. Suppl. 67, 357-375.

Souza, A.H., Cunha, A.P., Caraviello, D.Z., Wiltbank, M.C., 2005. Profiles of circulating estradiol-17 $\beta$ after different estrogen treatments in lactating dairy cows. Anim. Reprod. 2, 224-232.

Torres, J.R.S., Penteado, L., Sales, J.N.S., Sá Filho, M.F., Ayres, H., Baruselli, P.S., 2014. A comparison of two different esters of estradiol for the induction of ovulation in an estradiol plus progestin-based timed artificial insemination protocol for suckled Bos indicus beef cows. Anim. Reprod. Sci. 151, 9-14, http://dx.doi.org/10.1016/j.anireprosci.2014.09.019.

Vynckier, L., Debackere, M., De Kruif, A., Coryn, M., 1990. Plasma estradiol-17 beta concentrations in the cow during induced estrus and after injection of estradiol-17 beta benzoate and estradiol-17 beta cypionate - a preliminary study. J. Vet. Pharmacol. Ther. 13, 36-42.

Yavas, Y., Walton, J.S., 2000. Postpartum acyclicity in suckled beef cows: a review. Theriogenology 54, 25-55, http://dx.doi.org/10.1016/S0093-691X(00)00323-X. 